\title{
PHYSICO-CHEMICAL PROPERTIES AND ANTIOXIDANT ACTIVITY OF EXTRACTED ESSENTIAL OILS FROM IRRADIATED ROSEMARY LEAVES AND CLOVE BUDS
}

\author{
Wafaa, M. Shahin ${ }^{1 *}$, Hanan M.A. Al-sayed ${ }^{2}$ and Gebril $^{2}$ A.Y. \\ 1- Protection and Civel Defense Dept., Nuclear Research Center, Egyptian Atomic Energy \\ Authority P.O. Box. 13759, Abo-Zaabal, Kaluobia, Egypt \\ 2- Food Sci. Dept., Fac. of Agric. Ain Shams Univ., P.O. Box 68, Hadayek Shoubra11241, \\ Cairo, Egypt

$$
\text { *Corresponding author: fefe2002@yahoo.com }
$$

[120]

\section{ABSTRACT}

Rosemary and clove buds were irradiated with $\mathrm{Y}$-irradiation at different doses (0 to $30 \mathrm{kGy}$ ) and stored for 12 months at room temperature $(22 \pm 3$ $\left.{ }^{0} \mathrm{C}\right)$. The evaluation of irradiation depended on the chemical studies and antioxidant activity of extracted essential oils. Results showed significant difference for the essential oils yield at different doses during storage time. Compounds were fractionated and identified for extracted essential oils from each of non - irradiated and irradiated rosemary leaves and clove buds samples, the main components of essential oil extracted from either non-irradiated or irradiated rosemary were 1,8 cineole, camphor and $\mathrm{y}$-pinene 26.36, 12.63 and $16.98 \%$, respectively, while, eugenol was the major component in clove essential oil (which extracted from non-irradiated and irradiated samples (81.69\%). No differences were noticed in the \% of essential oils constituents. Antioxidant activity as \% of DPPH scavenging increased with the increasing of essential oils concentrations (250 up to $2500 \mathrm{ppm}$ ). Furthermore, the effect of adding these extracted oils from non-irradiated and irradiated samples as well as their mixture (1:1) on the threshold odor scores of sunflower oil was observed. Rancimat test shown the high oxidative stability in sunflower oil supplemented with $0.3 \%$ clove essential oil which extracted from 15kGy irradiated sample was $11.99 \mathrm{hrs}$, its relative stability was $144.11 \%$ comparing with the oxidative stability of sunflower oil supplemented with $0.5 \%$ rosemary essential oil extracted from nonirradiated sample $(9.76 \mathrm{hrs})$ with $117.3 \%$ relative stability.
\end{abstract}

Keywords: Rosemary leaves, Clove buds, Irradiation, Essential oil, GC/MS, Antioxidant activity, Rancimat

\section{INTRODUCTION}

Spices, aromatic and medicinal plants, are used in all of the food industry (Farag et al 1996), because of their properties as antimicrobial and antioxidant activities, due to their active compounds which determined by analytical techniques (Koleva et al 2001). Clove is a bud of a flowering Southeast Asia native tree (Syzygium aromaticum), and rosemary leaves is an evergreen shroud of Rosmarinus officinalis Lamiaceae, native to Mediterranean countries (Nurdjannah and Bermawie, 2012 and Tucker \& Maciarello, 1986). These plants are good and common example for aromatic plants which widely used in all over the world.

Volatile oils are produced from the primary secretions as secondary metabolites by aromatic plants, which are responsible for their smell, complex compounds obtained by each of distillation methods, localized in Mediterranean and tropical countries. Essential oil had a lot of properties: antimicrobial, antioxidant, antiseptic, antiinflammatory, analgesic and other medicinal properties, were used in food preservation due to their properties (Bakkali et al 2008). Rosemary and clove buds oils have high activities like: antimicrobial, antioxidant, and anti-inflammatory, these activities were due to presence of eugenol which the main component in the essential oils of those plants (Amariei et al 2013). 
Irradiation is known as an effective method for sterilization, pasteurization and food decontamination, considered as safe method (Alam Khan and Abrahem, 2010). Because of these reasons, food irradiation attracted around the world to use "Atoms for Peace" (Boisseau, 1994). Gamma irradiation process with specific doses under control is an effective technique to preserve spices comparing with microwave treatment, where it does not cause flavor compounds losing (Sadecka et al 2005). Each treatment of food causes changes in some of chemical properties of food, meanwhile, irradiation treatment causes a slight difference in these parameters as mentioned by (Salum et al 2009).

So, the aim of this study to evaluate the effect of gamma irradiation on the extracted essential oil, physico-chemical properties of extracted essential oils from rosemary leaves and clove buds and study their antioxidant activities.

\section{MATERIALS AND METHODS}

\section{Materials}

\subsection{Plant materials}

Dried rosemary leaves (Rosmarinus officinalis) were purchased at summer 2016 in June from ElMaghrabi Farm for aromatic plants, El-Nobareya, Egypt. Dried clove buds, (Syzygium aromaticum) were purchased at summer 2016 in June from a local market, Cairo, Egypt. Rosemary leaves and clove buds were kept in glass jars in room temperature $\left(22 \pm 3^{0} \mathrm{C}\right)$.

\subsection{Chemicals}

Butylated hydroxytoluene (BHT) as a synthetic antioxidant (of purity 99.9\%) was purchased from Sigma Chemical Company, U.S.A. 2, 2-diphenyl-11 picrylhydrazyl (DPPH) was purchased from Sigma-Aldrich, Germany and solvents were purchased from El- Nasr Pharmaceutical Chemicals Co., Cairo, Egypt.

\subsection{Sun flower oil}

Sun flower oil (Refined and free from artificial antioxidants) was purchased from ARMA for food industry Co., $10^{\text {th }}$ of Ramadan, Cairo, Egypt.

\section{Methods}

\subsection{Irradiation of plant materials}

Irradiation was performed in the National Center for Radiation Research and Technology (NCRRT), Nasr City, Cairo, Egypt. Samples (50 gm.) of rosemary leaves or clove buds were packed in sterilized polyethylene bags and tightly sealed. The packed samples were treated with 0 , $5,10,15,20,25$ and $30 \mathrm{kGy}$ of gamma rays using Russian gamma cell, Model Issledovatel utilizing Cobalt- 60 as an irradiation source with a dose rate of $2.5 \mathrm{kGy} / \mathrm{h}$ at $20^{\circ} \mathrm{C}$. All the samples were stored at laboratory conditions for 12 months at room temperature $\left(22 \pm 3^{0} \mathrm{C}\right)$ under a relative humidity of $50-70 \%$, till analysis after $0,3,6,9$ and 12 months.

\subsection{Extraction of essential oils}

Dried rosemary leaves as well as dried clove buds, which irradiated or non- irradiated were stored for 0,3,6,9 and 12 months at room temperature. The essential oils were extracted from the samples by steam distillation method for $6 \mathrm{hrs}$. as described by Guenther, (1961). The obtained essential oils were dried over anhydrous sodium sulfate and stored in dark bottles in refrigerator at $5 \pm 2^{0} \mathrm{C}$ until used.

\subsection{Identification of chemical components of extracted essential oils}

To identify the components of essential oils of dried rosemary leaves and dried clove buds, GC/MS analyses were done for those irradiated or non- irradiated and stored for 0,3,6,9 and 12 months at room temperature $\left(22 \pm 3^{\circ} \mathrm{C}\right)$ according to Damjanovic et al (2005) and Politeo et al (2006).

\subsection{Percentages of extracted essential oils}

The percentages of essential oils contents in either non irradiated or irradiated dried rosemary leaves as well as dried clove buds which stored for 12 months were determined according to AOAC (1996).

\subsection{Physicochemical properties of extracted} essential oils

Specific gravity, refractive index, acid value and ester value were determined according to British Pharmacopeia (2004). Solubility in diluted alcohol was determined according to European Pharmacopeia (2001).

\subsection{Evaluation of adding extracted essential} oils on the odor of sunflower oil

Odor evaluation was performed to illustrate the effect of adding rosemary leaves, clove buds essential oils and their mixture (1:1) at concentrations 

from irradiated rosemary leaves and clove buds

$(0.0 \%, 0.1 \%, 0.2 \%, 0.3 \%, 0.4 \%$ and $0.5 \% \mathrm{v} / \mathrm{v})$ to sunflower oil according to Ranganna, (1978), and the intensity of the odor was described according to El-Baroty, (1988) using the scale of 4 degree as following: $0=$ no odor, $1=$ very weak odor, $2=$ higher acceptable odor, and $3=$ non acceptable odor.

\subsection{Determination of the antioxidant activity of} extracted essential oils

\subsubsection{Measurement of scavenging activity}

The antioxidant activity of rosemary leaves and clove buds essential oils either non-irradiated or irradiated were measured in terms of hydrogen donating or radical scavenging ability, using the stable radical DPPH (2,2-diphenyl-1-picrylhydrazyl) according to the method of Brand-William et al (1995). Methanolic stock solutions of rosemary leaves and clove buds essential oils in different concentrations were made according to the method of Politeo et al (2006). The decrease in absorbance at $517 \mathrm{~nm}$ was determined with Jenway 6300 spectrophotometer after $1 \mathrm{~h}$ for all samples. Absorbance of the DPPH radical without antioxidant, (the control sample) was measured. Percent inhibition of the DPPH radical by the samples was calculated according to the formula of Yen and Duh, (1994) as follows:

$$
\% \text { Inhibition }=\left(\left(\boldsymbol{A}_{c(0)}-\boldsymbol{A}_{A(t)}\right) / \boldsymbol{A}_{c(0)}\right) \times 100 .
$$

Where: $A_{c}(0)$ is the absorbance of the control at time $=0 \mathrm{~min}$.

$A_{A}(t)$ is the absorbance of the antioxidant at time $=1 \mathrm{~h}$.

2.7.2 Measurement of different samples of sunflower oil which had different concentrations of extracted essential oils stability as a food system by Rancimat apparatus

The oxidative stability of sunflower oil as affected by the addition of the different concentration of studied essential oils or BHT was determined using A Metrohm Rancimat model 679 (Herisau, Switzerland). The oil samples for all determinations were randomized to determine their position in the heating block. (Farhoosh and Moosavi, 2007).

\subsection{Statistical analysis}

Comparisons between different treatments were carried out by two ways analysis variance (ANOVA) followed by Tukey-Kramer multiple comparison test according to SAS, (1996).

\section{RESULTS AND DISCUSSION}

Effect of $y$-irradiation process on the extracted essential oils content (\%) from either nonirradiated or irradiated rosemary leaves as well as clove buds samples.

Results are shown in Table (1) reporting the $\mathrm{Y}^{-}$ irradiation effect at different doses 0 up to $30 \mathrm{kGy}$ on essential oils content (\%). Also, explain the effect of storage at room temperature up to 12 months on the extracted essential oil from either rosemary leaves or clove buds as percentage. Significant $(p \leq 0.05)$ difference could be observed among all the samples, either irradiated or not for their essential oil contents. Non irradiated rosemary yielded $1.41 \%$ at zero time, with note that; the percentage of essential oil yield was significant $(p \leq 0.05)$ increased as irradiation dose increased up to $30 \mathrm{kGy}$, it was accounted as $2.23 \%$. Weather non- irradiated or irradiated samples showed significant $(p \leq 0.05)$ shortage for the essential oil content during storage, where found that, essential oil content (\%) of non-irradiated rosemary after 12 months was yielded $0.68 \%$, while, $30 \mathrm{kGy}$ irradiated rosemary yielded $1.31 \%$ after the same storage period. So, results appeared that, the highest essential oil content was $2.23 \%$ yielded from $30 \mathrm{kGy}$ irradiated rosemary at zero time, while, the lowest yield was $0.68 \%$ extracted from non-irradiated rosemary after 12 months.

The results are in agreement with Khattak and Simpson, (2010) who reported that, significant $(p \leq 0.05)$ changes were noticed in the extracted essential oil content after any kind of spices irradiated with different doses; they noticed maximum increasing $(10.5 \%)$ in the essential oil yield especially at 25KGy. Variyar et al (1997) reported that, irradiation causing cell wall structure disabling accompanied by the highest extraction rate of oil from tissue.

Irradiation effect of clove buds on the extracted essential oil present was illustrated in the same Table (1), the effect of storage on the oil content showing as can be inferred in the same table, the content of non-irradiated clove buds was $16.33 \%$ of essential oil at zero time of storage. While, this yield increased up to $18.03 \%$ with an increasing irradiation dose up to $30 \mathrm{kGy}$ with direct proportion; moreover, can be observed that, storage time induced decreasing in the extracted essential oil percentage for both samples. There is reverse fit between storage time and essential oil content, where found that, essential oil content of nonirradiated clove buds after 12 months storage was 
Table 1. Essential oil content (\%) of irradiated rosemary as well as clove buds during storage at $0,3,6,9$ and 12 months

\begin{tabular}{|c|c|c|c|c|c|c|c|}
\hline \multirow{2}{*}{$\begin{array}{l}\text { Storage periods } \\
\text { (months) }\end{array}$} & \multicolumn{7}{|c|}{ Irradiated doses (kGy) } \\
\hline & 0 & 5 & 10 & 15 & 20 & 25 & 30 \\
\hline & \multicolumn{7}{|c|}{ Rosemary } \\
\hline Zero time & $1.41^{\mathrm{GHIJ}}$ & $1.55^{\mathrm{F}}$ & $1.71^{\mathrm{DE}}$ & $1.85^{\mathrm{BC}}$ & $1.95^{\mathrm{B}}$ & $2.11^{\mathrm{A}}$ & $2.23^{A}$ \\
\hline 3 & $1.09^{\mathrm{OPQ}}$ & $1.24^{\mathrm{LMN}}$ & $1.39^{\text {HIJK }}$ & $1.52^{\mathrm{FG}}$ & $1.68^{\mathrm{E}}$ & $1.82^{\mathrm{CD}}$ & $1.96^{\mathrm{B}}$ \\
\hline 6 & $0.98^{\mathrm{QR}}$ & $1.12^{\mathrm{NOP}}$ & $1.28^{\mathrm{KLM}}$ & $1.34^{\mathrm{FGHI}}$ & $1.51^{\mathrm{FGH}}$ & $1.69^{\mathrm{E}}$ & $1.93^{\mathrm{BC}}$ \\
\hline 9 & $0.85^{\mathrm{ST}}$ & $0.94^{\mathrm{RS}}$ & $1.06^{P Q R}$ & $1.14^{\mathrm{NOP}}$ & $1.29^{\mathrm{JKLM}}$ & $1.34^{\mathrm{FGHI}}$ & $1.53^{\mathrm{FG}}$ \\
\hline \multirow[t]{2}{*}{12} & $0.68^{U}$ & $0.76^{\mathrm{TU}}$ & $0.84^{\mathrm{ST}}$ & $0.96^{\mathrm{RS}}$ & $1.09^{\mathrm{OPQ}}$ & $1.19^{\mathrm{MNO}}$ & $1.31^{\mathrm{IJKL}}$ \\
\hline & \multicolumn{7}{|c|}{ Clove buds } \\
\hline Zero time & $16.33^{\mathrm{GHI}}$ & $16.64^{\mathrm{EFG}}$ & $16.93^{\mathrm{CDE}}$ & $17.23^{\mathrm{BC}}$ & $17.48^{\mathrm{B}}$ & $17.95^{\mathrm{A}}$ & $18.03^{\mathrm{A}}$ \\
\hline 3 & $15.72^{\mathrm{LMNOP}}$ & $16.03^{\mathrm{IJKL}}$ & $16.32^{\mathrm{GHI}}$ & $16.58^{\mathrm{FG}}$ & $16.91^{\mathrm{CDE}}$ & $17.19^{\mathrm{BCD}}$ & $17.47^{\mathrm{B}}$ \\
\hline 6 & $15.48^{\mathrm{NOPQ}}$ & $15.77^{\mathrm{KLMNO}}$ & $16.08^{\mathrm{HIJK}}$ & $16.37^{\mathrm{GH}}$ & $16.62^{\mathrm{EFG}}$ & $16.89^{\mathrm{DEF}}$ & $17.43^{\mathrm{B}}$ \\
\hline 9 & $15.21^{\mathrm{QR}}$ & $15.42^{P Q}$ & $15.63^{\mathrm{MNOP}}$ & $15.79^{\mathrm{KLMN}}$ & $16.13^{\mathrm{HIJ}}$ & $16.38^{\mathrm{GH}}$ & $16.57^{\mathrm{FG}}$ \\
\hline 12 & $14.89^{R}$ & $15.06^{R}$ & $15.21^{\mathrm{QR}}$ & $15.46^{\mathrm{OPQ}}$ & $15.72^{\mathrm{LMNOP}}$ & $15.91^{\mathrm{JKLM}}$ & $16.14^{\mathrm{HIJ}}$ \\
\hline
\end{tabular}

Comparing information using the Tukey method and $95 \%$ confidence, means that dot not share a letter are significantly different.

The statistical analyses were done individually (in the same kind of essential oil).

$14.89 \%$, otherwise, essential oil content of 30kGy irradiated clove buds after 12 months was yielded $16.14 \%$. So that, as can be reported in Table (1), the highest essential oil content was $18.03 \%$ of $30 \mathrm{kGy}$ irradiated clove buds at zero time, meanwhile, the lowest essential oil yield was $14.89 \%$ of non-irradiated clove buds after 12 months of storage.

These results are in coincidence with Variyar et al (1998) results where they mentioned that irradiation processing induced increasing of clove essential oil content (18.88\%) comparison to the non-irradiated clove essential oil content (15.25\%). Stattie et al (2004) recorded that the total essential oil content for spices and medicinal herbs increased with $10 \mathrm{kGy}$ of gamma irradiation. Also, Suhaj and Horvathova, (2007) mentioned that clove irradiation processing induced increasing in the methanolic extraction yield during storage at $22 \pm 3^{\circ} \mathrm{C}$ for 5 months by $2 \%$, and $22 \%$ for irradiated ginger.

Identification of extracted essential oil components of either non irradiated or irradiated dried rosemary leaves

The essential oils from dried rosemary leaves which extracted were identified by GC/MS; the results are shown in Table (2). Thirty one compounds were identified for essential oil of the nonirradiated rosemary, represented $96.23 \%$, while unknown constituents was represented $3.77 \%$.
The fractioned components of rosemary essential oil results in Table (2) showed that 1,8cineole, a-pinene, camphore and camphen were found to be as the main compounds of the essential oil of non-irradiated rosemary leaves with the rate of percentage 26.36, 16.98, 12.63 and $5.65 \%$, respectively. These results are confirmed with Giordani et al (2004) who found that the presence of 1,8 cineole was $24.36 \%$ in rosemary leaves essential oil, Santoyo et al (2005) who recorded that 1,8 cineole, $\alpha$-pinene, camphor, Borneol and verbenone were the predominant compounds in rosemary essential oil representing about $80 \%$ of the total components of rosemary essential oil. In the same extracted essential oil of non-irradiated rosemary other components were also identified in the rosemary essential oil such as $\alpha$-thujene, $\beta$ pinene, sabinene, myrcene, $\alpha$-phylandrene, $p$ cymene, borneol, $\beta$-myrcene, verbenone and $\alpha$ Terpineol those representing $0.34,3.81,0.66$, $1.67,0.32,2.31,2.14,0.98$ and 1.82 and $2.28 \%$, respectively. These results are in agreement with 'Dimitrijevic' et al (2007). The essential oils of different irradiated rosemary samples with doses (5, 10, 15, 20, 25 and $30 \mathrm{kGy})$ were fractionated and identified by GC/MS; results are shown in the same Table (2). Thirty one compounds were identified, represented 96.22, 96.57, 96.59, 96.51, 96.59 and $96.72 \%$ for irradiated treatments by 5 , $10,15,20,25$ and $30 \mathrm{kGy}$, respectively. Also results show that, the $\mathrm{Y}$-irradiated rosemary by $30 \mathrm{kGy}$ caused a decreasing in content (\%) of 
Table 2. Percentages of the identified components for extracted essential oils of irradiated dry rosemary leaves

\begin{tabular}{|c|c|c|c|c|c|c|c|}
\hline \multirow[t]{2}{*}{ Compounds } & & \multicolumn{6}{|c|}{ Gamma irradiation dose(kGy) } \\
\hline & 0 & 5 & 10 & 15 & 20 & 25 & 30 \\
\hline$\beta$-Myrcene & 0.98 & 0.98 & 0.98 & 0.98 & 0.98 & 0.98 & 0.98 \\
\hline Tricyclene & 0.29 & 0.29 & 0.29 & 0.29 & 0.29 & 0.29 & 0.29 \\
\hline$\alpha$-Thujene & 0.34 & 0.32 & 0.30 & 0.29 & 0.27 & 0.26 & 0.24 \\
\hline$\alpha$-Pinene & 16.98 & 16.97 & 16.94 & 16.92 & 16.90 & 16.89 & 16.88 \\
\hline Camphene & 5.65 & 5.65 & 5.66 & 5.67 & 5.67 & 5.68 & 5.68 \\
\hline$\beta$-Pinene & 3.81 & 3.81 & 3.81 & 3.72 & 3.69 & 3.67 & 3.61 \\
\hline Sabinene & 0.66 & 0.66 & 0.66 & 0.66 & 0.66 & 0.66 & 0.66 \\
\hline Myrcene & 1.67 & 1.67 & 1.67 & 1.67 & 1.67 & 1.67 & 1.67 \\
\hline a-phylandrene & 0.32 & 0.31 & 0.33 & 0.32 & 0.31 & 0.31 & 0.31 \\
\hline y-3-Carene & 0.28 & 0.28 & 0.28 & 0.28 & 0.28 & 0.28 & 0.28 \\
\hline$\alpha$-Terpinene & 0.36 & 0.36 & 0.36 & 0.36 & 0.36 & 0.36 & 0.36 \\
\hline o-Cymene & 2.31 & 2.31 & 2.41 & 2.51 & 2.53 & 2.56 & 2.59 \\
\hline O-Cymene & 0.67 & 0.67 & 0.73 & 0.81 & 0.84 & 0.84 & 0.91 \\
\hline Limonene & 3.75 & 3.73 & 3.69 & 3.54 & 3.43 & 3.36 & 3.31 \\
\hline 1,8Cineole & 26.36 & 26.36 & 26.36 & 26.36 & 26.36 & 26.36 & 26.36 \\
\hline Y-Terpinene & 0.74 & 0.72 & 0.69 & 0.65 & 0.65 & 0.64 & 0.63 \\
\hline Terpinolene & 0.91 & 0.91 & 0.91 & 0.91 & 0.91 & 0.91 & 0.91 \\
\hline$\alpha$-Terpinolene & 0.20 & 0.2 & 0.2 & 0.2 & 0.2 & 0.2 & 0.2 \\
\hline Linalool & 2.39 & 2.39 & 2.37 & 2.34 & 2.3 & 2.3 & 2.29 \\
\hline Camphore & 12.63 & 12.63 & 12.63 & 12.63 & 12.63 & 12.63 & 12.63 \\
\hline Borneol & 2.14 & 2.14 & 2.14 & 2.14 & 2.14 & 2.14 & 2.14 \\
\hline Terpinene-4-ol & 0.97 & 0.95 & 0.94 & 0.93 & 0.89 & 0.88 & 0.86 \\
\hline$\alpha$-Terpineol & 2.28 & 2.28 & 2.29 & 2.29 & 2.28 & 2.28 & 2.28 \\
\hline Verbenone & 1.82 & 1.82 & 1.82 & 1.83 & 1.86 & 1.86 & 1.86 \\
\hline Citronellol & 0.17 & 0.17 & 0.17 & 0.17 & 0.17 & 0.17 & 0.17 \\
\hline Geraniol & 1.54 & 1.54 & 1.54 & 1.54 & 1.54 & 1.54 & 1.54 \\
\hline Bornyl acetate & 2.01 & 2.01 & 2.01 & 2.01 & 2.01 & 2.01 & 2.01 \\
\hline$\beta$-Caryophyllene & 1.75 & 1.73 & 1.72 & 1.7 & 1.68 & 1.67 & 1.67 \\
\hline Caryophyllene & 0.05 & 0.05 & 0.25 & 0.38 & 0.42 & 0.45 & 0.54 \\
\hline Caryophyllene oxide & 0.14 & 0.25 & 0.37 & 0.43 & 0.53 & 0.68 & 0.81 \\
\hline a-Humulene & 2.06 & 2.06 & 2.06 & 2.06 & 2.06 & 2.06 & 2.06 \\
\hline Total identified compounds $\%$ & 96.23 & 96.22 & 96.57 & 96.59 & 96.51 & 96.59 & 96.72 \\
\hline Total unidentified compounds $\%$ & 3.77 & 3.78 & 3.43 & 3.41 & 3.49 & 3.41 & 3.28 \\
\hline
\end{tabular}

some essential oils components as $\alpha$-pinene, $\alpha$ thujene, $\beta$-pinene, limonene, $\gamma$-Terpinene, linalool, Terpinene-4-ol and $\beta$-caryophyllene, those representing $16.88,0.24,3.61,3.31,0.63,2.29,0.86$ and $1.67 \%$, respectively. Meanwhile, the same dose of $\mathrm{y}$-irradiated samples induced increasing of some essential oils compounds as camphen, $\mathrm{p}$ cymene, o-cymene, verbenone, caryophyllene and caryophyllene oxide, represented 5.68, 2.59, 0.91, $1.86,0.54$ and $0.81 \%$, respectively. While, other essential oils compounds such as $\beta$-myrcene, sabinene, myrcene, $\alpha$-terpinene, 1,8cineole, camphor and borneol were not changed at any dose of $\mathrm{y}$ irradiation.
These results are in agreement with the results of Sadecka and Polovka, (2008); Machhour et al (2011); Silva et al (2013); Fatemi et al (2014); Elizalde and Espinoza, (2014) and Kirkin et al (2014). Those studies reported that the cause of induced changes is due to the ionizing radiation sensitively, for example, hydrocarbon can react sensitively with ionizing radiation and resulted reduction of monoterpenes such as $\alpha$-pinene and $\beta$-pinene and an increasing of sesquiterpenes as caryophyllene. Also, Al-shawi, (2016) noticed an increasing of the amount of limonene in essential oil of tested irradiated black pepper samples at different irradiation doses. 
Identification of extracted essential oil components of either non irradiated or irradiated dried clove buds

The essential oils which extracted from clove buds were identified by GC/MS; the results are shown in Table (3). Fourteen compounds were identified for the extracted oil from non- irradiated clove buds. They represented $99.97 \%$, and $0.03 \%$ for unknown components. Eugenol was considered as the major compound in clove essential oil accounted $81.69 \%$. The second major compound was indicated as eugenyl acetate, represented 8.31\%. Alshawi, (2016) reported that the amount of eugenol and eugenyl acetate in clove essential oil were $73.5 \%$ and $10.81 \%$, respectively. Caryophyllene was considered as moderate component that accounted $4.32 \%$. Other components were also fractioned such as $\alpha$-pinene, linalool, $\beta$ caryophyllene $\alpha$-Humulene, and $\Delta$-cadinene found in law quantities represented 0.47, 0.62, 1.73, 1.45 and $0.51 \%$, respectively, while, fractioned minor components such as $\gamma$-cadinene, $\beta$-cadinene, cisisoeugenol and $\delta$-cadinene represented 0.051 , $0.043,0.024$ and $0.002 \%$, respectively. Amelia et al (2017) reported that the amount of eugenol in clove essential oil was $74.64 \%$, eugenyl acetate represented $8.7 \%$, other components were also identified such as caryophyllene, $\alpha$-humulene, $\gamma$ cadinene, $\beta$-cadinene and caryophyllene oxide represented $12.79,1.53,0.034,0.039$ and $0.48 \%$, respectively.

The essential oils of different irradiated clove bud samples with doses $(5,10,15,20,25$ and $30 \mathrm{kGy}$ ) were fractioned and identified by GC/MS; results are shown in the same Table (3). Fourteen compounds were identified, represented 99.77, 99.902, 99.942, 99.723, 99.683and $99.741 \%$ for $\gamma$ irradiation treatments by $(5,10,15,20,25$ and $30 \mathrm{kGy}$, respectively. Results show that, the $\mathrm{Y}$ irradiated clove buds under different doses induced reduction of the percentage of some essential oils components as a-pinene, linalool, $\alpha$ humulene and $\beta$-caryophyllene at $30 \mathrm{kGy}$, those representing $0.4,0.32,1.19$ and $1.19 \%$, respectively. The recorded results also found that the decreasing in some essential oil components due to increasing of $y$-irradiation dose from 10up to $30 \mathrm{kGy}$, these results agree with those of Abozaid \& El-Sayed (2013) and Guat et al (2007). Generally, no exceptional changes were noticed in the essential oil components at low radiation doses that are confirmed as safe maximal dose (toxicologically and nutritionally) according to Wilkinson and Gould, (1998). The low dose of irradiation treatment is known to be as a cold physical process for food, due to the reason for ignoring a significant heating of product (the product temperature may rise by $\max 4^{\circ} \mathrm{C}$ at the dose of $10 \mathrm{kGy}$ ).

The results are in agreement with the results of Sadecka, (2010), reported that the most important change could be noticed at the dose of $30 \mathrm{kGy}$, as well as the configurationally change can caused by high irradiation dose, such as changes in the double bonds positions and functional groups. On the other hand, in the results of this study, the increasing of caryophyllene oxide by increasing the dose of irradiation process may be due to the reaction between terpens and free radicals which can generate from the water contained in spices (approx.. $10 \%$ ) as indirect effect or by which of hydroxylation or oxidation of the aromatic ring of terpene to produce terpene oxides or terpene alcohole according to Urbian, (1986).

Physico-chemical properties of extracted essential oils from either non-irradiated or irradiated dried rosemary leaves and dried clove buds

The results of Physico-chemical properties of the non-irradiated and irradiated rosemary leaves and clove buds essential oils are shown in Table (4).

Specific gravity at $20^{\circ} \mathrm{C}$ of the essential oils from rosemary or clove buds at 0kGy was 0.896 and 1.047 , respectively. The specific gravity values of each sample showed some changes that can be observed throughout the irradiation process. The value of extracted essential oil from irradiated rosemary at $10 \mathrm{kGy}$ was 0.900 , while, increased up to 0.916 at $30 \mathrm{kGy}$. The results of $\mathrm{y}$-irradiated clove buds showed the same changes for its essential oils, the specific gravity values changed from 1.048 at $5 \mathrm{kGy}$ to 1.063 at $20 \mathrm{kGy}$, changed also to 1.068 at 30kGy.

Refractive index of the rosemary essential oils or clove buds showed slightly increments, it could be noticed for extracted essential oils from $Y$ irradiated rosemary and clove buds as a results of irradiation process, refractive index of rosemary essential oil was $1.4700,1.4900$ at 0kGy and 30kGy, respectively, while, was $1.5360,1.5560$ for the clove buds essential oil at the same doses.

From the same Table (4), solubility in ethyl alcohol of rosemary essential oil changed from 1.6 for non-irradiated to 2.6 for irradiated at $30 \mathrm{kGy}$; meanwhile it changed from 1.4 to 2.5 for clove buds essential oil at the same conditions. 

from irradiated rosemary leaves and clove buds

Table 3. Percentages of the identified components for extracted essential oils of irradiated dry clove buds

\begin{tabular}{|l|c|c|c|c|c|c|c|}
\hline \multirow{2}{*}{ Compounds } & \multicolumn{7}{|c|}{ Gamma irradiation dose(kGy) } \\
\cline { 2 - 8 } & $\mathbf{0}$ & $\mathbf{5}$ & $\mathbf{1 0}$ & $\mathbf{1 5}$ & $\mathbf{2 0}$ & $\mathbf{2 5}$ & $\mathbf{3 0}$ \\
\hline $\boldsymbol{\alpha}$-pinene & 0.47 & 0.47 & 0.46 & 0.45 & 0.43 & 0.41 & 0.4 \\
Linalool & 0.62 & 0.62 & 0.6 & 0.57 & 0.51 & 0.4 & 0.32 \\
Copaene & 0.13 & 0.13 & 0.34 & 0.36 & 0.39 & 0.41 & 0.43 \\
Eugenol & 81.69 & 81.69 & 81.69 & 81.76 & 81.8 & 81.9 & 82.1 \\
$\boldsymbol{\beta}$-caryophyllene & 1.73 & 1.73 & 1.7 & 1.62 & 1.51 & 1.32 & 1.19 \\
caryophyllene & 4.32 & 4.32 & 4.41 & 4.48 & 4.51 & 4.53 & 4.58 \\
caryophyllene oxide & 0.62 & 0.62 & 0.62 & 0.62 & 0.62 & 0.76 & 0.76 \\
$\boldsymbol{\alpha}$-Humulene & 1.45 & 1.45 & 1.21 & 1.21 & 1.19 & 1.19 & 1.19 \\
Y-cadinene & 0.051 & 0.051 & 0.053 & 0.053 & 0.054 & 0.054 & 0.062 \\
$\boldsymbol{\beta}$-cadinene & 0.043 & 0.043 & 0.043 & 0.043 & 0.043 & 0.043 & 0.043 \\
ס-cadinene & 0.002 & 0.002 & 0.002 & 0.002 & 0.002 & 0.002 & 0.002 \\
cis-isoeugenol & 0.024 & 0.024 & 0.024 & 0.024 & 0.024 & 0.024 & 0.024 \\
$\boldsymbol{\Delta}$-cadinene & 0.51 & 0.51 & 0.51 & 0.51 & 0.51 & 0.51 & 0.51 \\
Eugenyl acetate & 8.31 & 8.11 & 8.24 & 8.24 & 8.13 & 8.13 & 8.13 \\
Total identified compounds\% & 99.97 & 99.77 & 99.902 & 99.942 & 99.723 & 99.683 & 99.741 \\
Total unidentified compounds\% & 0.03 & 0.23 & 0.098 & 0.058 & 0.277 & 0.317 & 0.259 \\
\hline
\end{tabular}

Table 4. Physico-chemical properties of extracted essential oils from dry rosemary leaves as well as dry clove buds either non-irradiated or irradiated

\begin{tabular}{|c|c|c|c|c|c|c|c|}
\hline \multirow[t]{2}{*}{ Property } & \multicolumn{7}{|c|}{ Dose of $\mathrm{Y}$-irradiation(kGy) } \\
\hline & 0 & 5 & 10 & 15 & 20 & 25 & 30 \\
\hline & \multicolumn{7}{|c|}{ Rosemary } \\
\hline Specific gravity at $20^{\circ} \mathrm{C}$ & 0.896 & 0.897 & 0.900 & 0.904 & 0.912 & 0.917 & 0.916 \\
\hline$\%$ change & 100 & 100.1 & 100.4 & 100.8 & 101.7 & 102.3 & 102.2 \\
\hline Refractive index at $20^{\circ} \mathrm{C}$ & 1.4700 & 1.4700 & 1.4750 & 1.4770 & 1.4890 & 1.4930 & 1.4900 \\
\hline \%change & 100 & 100 & 100.43 & 100.47 & 101.29 & 101.56 & 101.36 \\
\hline Solubility in alcohol $90 \%$ & 1.6 & 1.6 & 1.6 & 1.6 & 2.1 & 2.3 & 2.6 \\
\hline \%change & 100 & 100 & 100 & 100 & 131.25 & 143.75 & 162.5 \\
\hline Acid value $\mathrm{mg} \mathrm{KOH} / \mathrm{g}$ oil & 0.41 & 0.42 & 0.49 & 0.5 & 0.51 & 0.516 & 0.52 \\
\hline \%change & 100 & 102.43 & 119.51 & 121.95 & 124.39 & 125.85 & 126.82 \\
\hline Ester number $\mathrm{mg} \mathrm{KOH/g}$ oil & 2.91 & 2.9 & 2.88 & 2.83 & 2.81 & 2.61 & 2.37 \\
\hline \multirow[t]{2}{*}{ \%change } & 100 & 99.65 & 98.96 & 97.25 & 96.56 & 89.69 & 81.44 \\
\hline & \multicolumn{7}{|c|}{ Clove buds } \\
\hline Specific gravity at $20^{\circ} \mathrm{C}$ & 1.047 & 1.048 & 1.0518 & 1.0558 & 1.063 & 1.067 & 1.068 \\
\hline \%change & 100 & 100.09 & 100.45 & 100.84 & 101.52 & 101.91 & 102.0 \\
\hline Refractive index at $20^{\circ} \mathrm{C}$ & 1.5360 & 1.5360 & 1.5410 & 1.5430 & 1.5550 & 1.5590 & 1.5560 \\
\hline \%change & 100 & 100 & 100.32 & 100.45 & 101.23 & 101.49 & 101.3 \\
\hline Solubility in alcohol $90 \%$ & 1.4 & 1.4 & 1.4 & 1.4 & 1.9 & 2.1 & 2.5 \\
\hline \%change & 100 & 100 & 100 & 100 & 135.71 & 150 & 178.57 \\
\hline Acid value $\mathrm{mg} \mathrm{KOH} / \mathrm{g}$ oil & 3.68 & 3.67 & 3.74 & 3.75 & 3.77 & 3.77 & 3.8 \\
\hline \%change & 100 & 99.72 & 101.63 & 101.9 & 102.44 & 102.44 & 103.26 \\
\hline Ester number mg KOH/g oil & 1.84 & 1.83 & 1.8 & 1.75 & 1.73 & 1.54 & 1.29 \\
\hline$\%$ change & 100 & 99.45 & 97.82 & 95.1 & 94.02 & 83.69 & 70.1 \\
\hline
\end{tabular}


Results recorded that, the acid values of the tested oils, were 0.41 and $3.68 \mathrm{mg} \mathrm{KOH} / 1 \mathrm{~g}$ oil for rosemary and clove buds essential oils, respectively, which extracted from non- irradiated sample. While, observed data showed an incremental pattern in this parameter among different doses of irradiation, it reached 0.52 and $3.8 \mathrm{mgKOH} / \mathrm{g}$ oil for rosemary and clove buds essential oils at 30kGy, respectively.

Results in Table (4) show the values of ester number of rosemary and clove buds essential oils from non - irradiated and irradiated samples, the values were 2.91, 2.88, 2.61 and $2.37 \mathrm{mg} \mathrm{KOH} / 1 \mathrm{~g}$ oil for rosemary essential oils at $0,10,25$ and $30 \mathrm{kGy}$, respectively; while, were 1.84, 1.8, 1.54 and $1.29 \mathrm{mg} \mathrm{KOH} / 1 \mathrm{~g}$ oil for clove buds essential oil at the same dose.

The results of physic-chemical properties are in agreement with Atti-Santose et al (2005); Clarke, (2008); Bousbia et al (2009); Burdock, (2010) and Egyptian Standards, (2007).

Antioxidant activity of extracted essential oils from both non-irradiated and irradiated rosemary leaves and clove buds

Rosemary essential oils extracted from irradiated samples at doses ( 0 up to 30kGy) were tested at different concentrations to evaluate their antioxidant activities measured as \% stable radical DPPH scavenging compared with $\mathrm{BHT}$ at $200 \mathrm{ppm}$, results are shown in Table (5). Results recorded that, increasing the essential oil concentrations from 250 to $2500 p p m$, were accompanied by significant $(p \leq 0.05)$ increasing of \%DPPH scavenging. Antioxidant activity of essential oils refer to the present of active compounds such as 1,8 cineole, because of the high percentage of main constituents or the presence of minor components, also, can be due to synergy among essential oil components (Politeo et al 2006). Furthermore, Yanishlieva and Marinova, (1998); as well as Tsai et al (2007) they recorded that, phenolic compounds can stop the reaction of propagation chain by donating hydrogen atom to free radicals during lipid oxidation.

Results are shown that the \% of DPPH scavenging of BHT at 200ppm was the lowest activity $(7.662 \%)$, moreover the percentage of DPPH scavenging for rosemary essential oil extracted from non-irradiated sample at $250 \mathrm{ppm}$ was $22.23 \%$ higher than the DPPH inhibition \% of BHT (as a reference), concentration 250ppm of the essential oil extracted from irradiated rosemary at
$30 \mathrm{kGy}$ is the lowest scavenging activity (21.42\%) of all irradiated samples, while, scavenging ability of 2500ppm of the same essential oil at 0kGy was the highest. Regarding to fractionating and identifying compound by GC/MS, camphor is an oxygenated compound has an antioxidant properties according to Wang et al (2008) who reported that camphor and borneol are the cause of antioxidant activity, meanwhile, Yosr et al (2013) recorded that Tunisian rosemary essential oil had high percentage of camphor, a-pinene and 1,8 cineol caused high antioxidant activity of rosemary essential oil. These results are in agreement with Bobilev et al (2011) and Zegura et al (2011) who reported that, rosemary had strong antioxidant properties, also, Yesilbag et al (2011) reported that rosemary has high ability displaying good antioxidant effects. Significant differences could be noticed for each concentration at different irradiation dose. The increase of irradiation dose induced slightly decreasing in \%DPPH scavenging for most of the different concentrations of essential oil. These results are in agreement with Suhaj et al (2006) and Kim et al (2009).

Clove essential oils extracted from irradiated samples at diversity doses from 0 to $30 \mathrm{kGy}$ were studied at different concentration (250 up to 2500ppm) to determine their antioxidant activities evaluating as \% DPPH scavenging in comparison with BHT (200ppm) as a reference, results are shown in Table (5). Increasing \% of DPPH scavenging combined with the increasing in clove essential oil concentration, clove essential oil in concentration $250 \mathrm{ppm}$ at $30 \mathrm{kGy}$ was the lowest scavenging activity (45.218) of all irradiated samples, although the scavenging activity of $\mathrm{BHT}$ was lower than it; while, scavenging ability of 2500ppm of the same essential oil at different doses of $5,10,15$, 20 and 25 had the highest values of scavenging. Decreasing in DPPH concentration significantly due to the antioxidant ability of clove oil, clove oil scavenging activity is the highest in comparison with BHT, a-tocopherol, BHA and trolox, as mentioned by Gulcin et al (2012) and Rojas-Cortes, et al (2014) reported that clove essential oil has high percentage of antioxidant compounds as food preservative, Ibrahium et al (2013) noticed the effect of clove essential oil on cake preservation due to its antioxidant activity in order to avoid synthetic antioxidant which has harmful effects. Regarding to identification of compounds by GC/MS, the antioxidant activity of clove oil caused by its main compound eugenol. 
Table 5. Antioxidant activity of extracted essential oils from either non-irradiated or irradiated rosemary leaves and clove buds

\begin{tabular}{|c|c|c|c|c|c|c|}
\hline \multirow{2}{*}{$\begin{array}{l}\text { Y-irradiation } \\
\text { dose (kGy) }\end{array}$} & \multicolumn{6}{|c|}{ Concentration of essential oil(ppm) } \\
\hline & 250 & 500 & 1000 & 1500 & 2000 & 2500 \\
\hline & & & Rosemary & & & \\
\hline 0 & $22.23^{\mathrm{S}}$ & $31.36^{\mathrm{O}}$ & $45.91^{\mathrm{K}}$ & $60.72^{\prime}$ & $69.47^{\mathrm{C}}$ & $71.31^{\mathrm{A}}$ \\
\hline 5 & $22.11^{\mathrm{s}}$ & $31.26^{\mathrm{O}}$ & $45.74^{\mathrm{KL}}$ & $60.64^{1}$ & $69.28^{C D}$ & $71.22^{\mathrm{AB}}$ \\
\hline 10 & $22.01^{\mathrm{ST}}$ & $30.71^{P}$ & $45.63^{\mathrm{KLM}}$ & $60.53^{\mathrm{IJ}}$ & $69.17^{\mathrm{DE}}$ & $71.13^{\mathrm{AB}}$ \\
\hline 15 & $21.74^{\mathrm{TU}}$ & $30.64^{P}$ & $45.54^{\mathrm{LM}}$ & $60.31^{\mathrm{J}}$ & $69.09^{\mathrm{DEF}}$ & $71.11^{\mathrm{AB}}$ \\
\hline 20 & $21.69^{\mathrm{UV}}$ & $30.51^{P Q}$ & $45.46^{\mathrm{LMN}}$ & $62.13^{\mathrm{H}}$ & $69.03^{\mathrm{DEF}}$ & $71.07^{\mathrm{AB}}$ \\
\hline 25 & $21.53^{\mathrm{UV}}$ & $30.34^{\mathrm{QR}}$ & $45.37^{\mathrm{MN}}$ & $62.37^{\mathrm{H}}$ & $68.91^{\mathrm{EF}}$ & $70.93^{B}$ \\
\hline 30 & $21.42^{\mathrm{V}}$ & $30.17^{\mathrm{R}}$ & $45.19^{N}$ & $60.62^{1}$ & $68.82^{\mathrm{FG}}$ & $68.54^{G}$ \\
\hline \multirow[t]{2}{*}{ ВHT(200ppm) } & \multicolumn{6}{|c|}{7.662} \\
\hline & \multicolumn{6}{|c|}{ Clove buds } \\
\hline 0 & $46.666^{S}$ & $55.291^{\mathrm{O}}$ & $68.799^{\mathrm{LM}}$ & $83.009^{G}$ & $92.989^{\mathrm{B}}$ & $93.912^{\mathrm{A}}$ \\
\hline 5 & $46.08^{\top}$ & $55.161^{\mathrm{OP}}$ & $68.571^{\mathrm{LMN}}$ & $82.818^{\mathrm{GH}}$ & $92.723^{\mathrm{BC}}$ & $93.98^{\mathrm{A}}$ \\
\hline 10 & $45.79^{\mathrm{TU}}$ & $54.97^{\mathrm{OPQ}}$ & $68.43^{\mathrm{LMN}}$ & $82.704^{\mathrm{GHI}}$ & $92.586^{\mathrm{BCD}}$ & $93.864^{\mathrm{A}}$ \\
\hline 15 & $45.71^{\text {TUV }}$ & $54.79^{\mathrm{OPQR}}$ & $68.34^{\mathrm{MN}}$ & $81.028^{\mathrm{K}}$ & $92.456^{\mathrm{CDE}}$ & $93.775^{\mathrm{A}}$ \\
\hline 20 & $45.523^{U V}$ & $54.704^{P Q R}$ & $68.212^{N}$ & $82.361^{\mathrm{HI}}$ & $92.266^{\mathrm{CDE}}$ & $93.639^{A}$ \\
\hline 25 & $45.333^{U V}$ & $54.567^{\mathrm{QR}}$ & $68.113^{\mathrm{N}}$ & $82.209^{1}$ & $92.113^{\mathrm{DE}}$ & $93.536^{\mathrm{A}}$ \\
\hline 30 & $45.218^{V}$ & $54.399^{R}$ & $68.885^{\mathrm{L}}$ & $81.607^{\mathrm{J}}$ & $91.961^{\mathrm{E}}$ & $86.536^{\mathrm{F}}$ \\
\hline ВHT(200ppm) & \multicolumn{6}{|c|}{7.662} \\
\hline
\end{tabular}

Comparing information using the Tukey method and $95 \%$ confidence, means that dot not share a letter are significantly different.

The statistical analyses were done individually (in the same kind of essential oil).

Acceptable odor levels of both non-irradiated and irradiated rosemary as well as clove buds added to sunflower oil

Rosemary as well as clove buds essential oils extracted from either non-irradiated or irradiated samples and their mixture $(1: 1)$, added to sunflower oil in different concentrations $0.0,0.1,0.2,0.3$, 0.4 and $0.5 \%$ conducting to notice the convenient concentrations of these essential oils to have acceptable odor of sunflower oil and the results are shown in Table (6). The statistical analysis of results showed that, the odor of all sunflower oils supplemented with different concentrations of essential oils extracted from irradiated rosemary, clove buds and their mixture(1:1) were significantly difference $(p \leq 0.05)$ compared with control sunflower oil without any essential oil.

On the other hand, sunflower oil supplemented with $0.0 \%$ rosemary, clove buds essential oils extracted from either non-irradiated or irradiated samples and their mixture (1:1) recorded values whith no odor, while, $0.1,0.2,0.3$ and $0.4 \%$ rosemary oil extracted from all samples added to sunflower oil appeared very weak odor. The results show also that, 0.1 and $0.2 \%$ clove buds oils extracted from non-irradiated and irradiated which added to sunflower oil recorded mean values that very weak odor except at 30kGy which recorded the highest acceptable odor. From the same table, sunflower oil supplemented with $0.1,0.2$ and $0.3 \%$ of rosemary and clove buds and mixture (1:1) oils extracted from non-irradiated and irradiated samples had very weak odor values. From the results, it can be concluded that, the best concentrations of essential oils added to sunflower oil were $0.5,0.3$ and $0.4 \%$ for rosemary, clove buds essential oils extracted from either non-irradiated or irradiated samples and their mixture $(1: 1)$ these results coincided with those of to El-Baroty, (1988), Lucchesi, et al (2004), those reported that, the compounds of rosemary essential oil tend to have herbal aroma such as 1,8 cineol and camphor.

Effect of different concentrations of irradiated rosemary leaves, clove buds and their mixture (1:1) essential oils on the oxidative stability of sunflower oil assessed by Rancimat

Experiments conducting to evaluate the oxidative stability of sunflower oil supplemented with $0.5 \%$ rosemary essential oils extracted from nonirradiated irradiated samples as well as $0.3 \%$ of clove buds essential oils extracted from nonirradiated and irradiated samples and $0.4 \%$ their 
Table 6. Effect of irradiation on the threshold score of rosemary, clove buds and their mixture (1:1) essentials oil added to sun flower oil (Mean of acceptable odor levels)

\begin{tabular}{|c|c|c|c|c|c|c|c|}
\hline \multirow{2}{*}{ Concentration } & \multicolumn{7}{|c|}{ Dose of $y$-irradiation } \\
\hline & OkGy & $5 k G y$ & 10kGy & 15kGy & 20kGy & 25kGy & 30kGy \\
\hline & \multicolumn{7}{|c|}{ Rosemary } \\
\hline 0.0 & $0.53^{P}$ & $0.54^{P}$ & $0.57^{P}$ & $0.59^{P}$ & $0.59^{P}$ & $0.61^{P}$ & $0.63^{P}$ \\
\hline 0.1 & $0.93^{\circ}$ & $1.05^{\mathrm{NO}}$ & $1.11^{\mathrm{MN}}$ & $1.17^{\mathrm{LMN}}$ & $1.18^{\mathrm{LMN}}$ & $1.21^{\mathrm{LM}}$ & $1.23^{\mathrm{KLM}}$ \\
\hline 0.2 & $1.26^{\mathrm{JKL}}$ & $1.236^{\mathrm{KLM}}$ & $1.31^{\mathrm{JKL}}$ & $1.38^{\mathrm{HIJ}}$ & $1.39^{\mathrm{GHIJ}}$ & $1.36^{\mathrm{IJK}}$ & $1.38^{\mathrm{HIJ}}$ \\
\hline 0.3 & $1.47^{\mathrm{FGHI}}$ & $1.51^{\mathrm{EFGH}}$ & $1.61^{\mathrm{BCDEF}}$ & $1.64^{\mathrm{BCDE}}$ & $1.66^{\mathrm{BCD}}$ & $1.68^{\mathrm{BC}}$ & $1.7^{\mathrm{B}}$ \\
\hline 0.4 & $1.53^{\mathrm{DEFG}}$ & $1.54^{\mathrm{CDEF}}$ & $1.63^{\mathrm{BCDE}}$ & $1.65^{\mathrm{BCDE}}$ & $1.67^{\mathrm{BCD}}$ & $1.68^{\mathrm{BC}}$ & $1.71^{\mathrm{B}}$ \\
\hline \multirow[t]{2}{*}{0.5} & $2.11^{\mathrm{A}}$ & $2.09^{A}$ & $2.13^{\mathrm{A}}$ & $2.17^{\mathrm{A}}$ & $2.18^{A}$ & $2.2^{\mathrm{A}}$ & $2.23^{A}$ \\
\hline & \multicolumn{7}{|c|}{ Clove buds } \\
\hline 0.0 & $0.78^{J}$ & $0.82^{J}$ & $0.87^{J}$ & $0.87^{J}$ & $0.88^{J}$ & $0.91^{\mathrm{J}}$ & $0.94^{\mathrm{J}}$ \\
\hline 0.1 & $1.69^{l}$ & $1.86^{\mathrm{HI}}$ & $1.89^{\mathrm{H}}$ & $1.91^{\mathrm{H}}$ & $1.92^{\mathrm{H}}$ & $1.94^{\mathrm{H}}$ & $1.96^{\mathrm{H}}$ \\
\hline 0.2 & $1.87^{\mathrm{HI}}$ & $1.93^{\mathrm{H}}$ & $1.92^{\mathrm{H}}$ & $1.953^{\mathrm{H}}$ & $1.95^{\mathrm{H}}$ & $1.98^{\mathrm{H}}$ & $2.00^{\mathrm{GH}}$ \\
\hline 0.3 & $2.19^{F G}$ & $2.25^{\mathrm{F}}$ & $2.26^{\mathrm{EF}}$ & $2.27^{\mathrm{EF}}$ & $2.27^{\mathrm{EF}}$ & $2.28^{\mathrm{EF}}$ & $2.32^{\mathrm{CDEF}}$ \\
\hline 0.4 & $2.21^{\mathrm{F}}$ & $2.27^{\mathrm{EF}}$ & $2.28^{\mathrm{EF}}$ & $2.31^{\mathrm{DEF}}$ & $2.32^{\mathrm{CDEF}}$ & $2.34^{\mathrm{CDEF}}$ & $2.35^{\mathrm{BCDEF}}$ \\
\hline \multirow[t]{2}{*}{0.5} & $2.45^{\mathrm{ABCDE}}$ & $2.49^{A B C D}$ & $2.51^{\mathrm{ABC}}$ & $2.54^{\mathrm{AB}}$ & $2.54^{\mathrm{AB}}$ & $2.56^{A}$ & $2.58^{A}$ \\
\hline & \multicolumn{7}{|c|}{ Their mixture (1:1) } \\
\hline 0.0 & $0.46^{J}$ & $0.46^{J}$ & $0.46^{J}$ & $0.48^{J}$ & $0.51^{J}$ & $0.53^{J}$ & $0.54^{J}$ \\
\hline 0.1 & $1.44^{\prime}$ & $1.47^{1}$ & $1.48^{1}$ & $1.51^{\mathrm{HI}}$ & $1.52^{\mathrm{GHI}}$ & $1.56^{\mathrm{FGHI}}$ & $1.58^{\mathrm{EFGHI}}$ \\
\hline 0.2 & $1.46^{l}$ & $1.48^{\prime}$ & $1.49^{\prime}$ & $1.496^{\prime}$ & $1.56^{\mathrm{FGHI}}$ & $1.58^{\mathrm{EFGHI}}$ & $1.59^{\mathrm{EFGHI}}$ \\
\hline 0.3 & $1.69^{\mathrm{DEFGH}}$ & $1.71^{\mathrm{DE}}$ & $1.7^{\mathrm{DEFG}}$ & $1.72^{\mathrm{DEF}}$ & $1.74^{\mathrm{DEF}}$ & $1.76^{\mathrm{CDE}}$ & $1.78^{\mathrm{CD}}$ \\
\hline 0.4 & $1.93^{C}$ & $2.13^{\mathrm{B}}$ & $2.17^{\mathrm{B}}$ & $2.19^{B}$ & $2.2^{\mathrm{B}}$ & $2.25^{\mathrm{B}}$ & $2.26^{\mathrm{B}}$ \\
\hline 0.5 & $2.53^{A}$ & $2.58^{\mathrm{A}}$ & $2.62^{\mathrm{A}}$ & $2.64^{\mathrm{A}}$ & $2.65^{\mathrm{A}}$ & $2.546^{\mathrm{A}}$ & $2.71^{\mathrm{A}}$ \\
\hline
\end{tabular}

Comparing information using the Tukey method and $95 \%$ confidence, means that dot not share a letter are significantly different.

The statistical analyses were done individually (in the same kind of essential oil).

mixture (1:1) essential oils which extracted from non-irradiated as well as irradiated samples, by irradiation doses 5,10 and $15 \mathrm{kGy}$, comparing to sunflower oil without any antioxidants as control and sunflower oil supplemented with $0.02 \%$ BHT as synthetic antioxidant.

The results of oxidative stability and relative stability are shown in Table (7), the results revealed that, the oxidative stability of sunflower oil without any antioxidants as control recorded 8.32 hrs with relative stability $100 \%$, while, the oxidative stability of sunflower oil supplemented with $0.02 \% \mathrm{BHT}$ represented $13.6 \mathrm{hrs}$ with relative stability $163.46 \%$. Otherwise, adding different concentrations of rosemary, clove buds essential oils which extracted from different irradiation doses samples and their mixture (1:1) caused slightly increasing in oxidative stability of sunflower oil. Results illustrated that sunflower oil supplemented with $0.5 \%$ rosemary essential oil which extracted from non-irradiated sample had the lowest oxidative stability $(9.76 \mathrm{hrs})$ with relative stability $117.3 \%$ comparing to other treatments but still higher than the oxidative stability of control sample; while oxi- dative stability of sunflower oil supplemented with $0.3 \%$ clove buds essential oil extracted from $15 \mathrm{kGy}$ irradiated sample was the highest value reported $11.99 \mathrm{hrs}$ with relative stability $144.11 \%$.

Regarding to the results in Table (7), it could be observed that, the increasing of irradiation doses caused an enhancement in the oxidative stability, comparing to control one. Moreover, addition both of $0.5,0.3$ and $0.4 \%$ of rosemary, clove buds and their mixture (1:1), respectively. Essential oils extracted from different doses irradiated $(0,5,10$ and $15 \mathrm{kGy}$ ) samples to sunflower oil caused increasing of oxidative stability of sunflower oil which recorded $9.76,9.81,9.83$ and $9.84 \mathrm{hrs}$, respectively, for $0.5 \%$ rosemary oils; $11.86,11.93,11.96$ and $11.99 \mathrm{hrs}$, respectively for $0.3 \%$ clove buds oils as well as $10.33,10.41,10.42$ and $10.44 \mathrm{hrs}$, respectively for $0.4 \%$ mixture oils $(1: 1)$. This is due to antioxidant activities of essential oils which inhibiting the oxidation and have radical scavenging as mentioned by Bensmira et al (2007). Also, Rossel, 1989 reported that, the oxidative stability is a direct index for oxidation changes. 

from irradiated rosemary leaves and clove buds

Table 7. Effect of different concentrations of irradiated rosemary leaves, clove buds essential oils and their mixture on the oxidative stability of sunflower oil assessed by Rancimat test

\begin{tabular}{|c|c|c|c|c|c|c|c|c|}
\hline \multirow[b]{3}{*}{ Concentrations } & \multicolumn{8}{|c|}{ Irradiated treatments } \\
\hline & \multicolumn{2}{|c|}{ OkGy } & \multicolumn{2}{|c|}{$5 k G y$} & \multicolumn{2}{|c|}{ 10kGy } & \multicolumn{2}{|c|}{ 15kGy } \\
\hline & $\begin{array}{c}\text { Stability } \\
\text { (hrs) }\end{array}$ & $\begin{array}{c}\text { Relative } \\
\text { stability } \\
(\%)\end{array}$ & $\begin{array}{c}\text { Stability } \\
\text { (hrs) }\end{array}$ & $\begin{array}{c}\text { Relative } \\
\text { stability } \\
(\%)\end{array}$ & $\begin{array}{c}\text { Stability } \\
\text { (hrs) }\end{array}$ & $\begin{array}{c}\text { Relative } \\
\text { stability } \\
(\%)\end{array}$ & $\begin{array}{c}\text { Stability } \\
\text { (hrs) }\end{array}$ & $\begin{array}{c}\text { Relative } \\
\text { stability } \\
(\%)\end{array}$ \\
\hline SFO+0.5IR & 9.76 & 117.3 & 9.81 & 117.9 & 9.83 & 118.14 & 9.84 & 118.26 \\
\hline SFO+0.3ICL & 11.86 & 142.54 & 11.93 & 143.38 & 11.96 & 143.75 & 11.99 & 144.11 \\
\hline SFO+0.4IM & 10.33 & 124.15 & 10.41 & 125.12 & 10.42 & 125.24 & 10.44 & 125.48 \\
\hline $\begin{array}{l}\text { Control sunflower } \\
\text { oil }\end{array}$ & 8.32 & 100 & & & & & & \\
\hline $\begin{array}{c}\text { Sunflower oil with } \\
0.02 \% \text { BHT }\end{array}$ & 13.6 & 163.46 & & & & & & \\
\hline
\end{tabular}

SFO+0.5IR: Sunflower oil supplemented with $0.5 \%$ rosemary oil extracted from either non-irradiated or irradiated samples.

SFO+0.3ICL: Sunflower oil supplemented with $0.3 \%$ clove buds oil extracted from either non-irradiated or irradiated samples.

SFO+0.4IM: Sunflower oil supplemented with $0.4 \%$ mixture $(1: 1)$ of rosemary and clove buds oil extracted from either non-irradiated or irradiated samples.

hrs: Hours.

\section{REFERENCES}

Abozid M.M. and El-Sayed S.M. 2013. Antioxidant and protective effect of clove extracts and clove essential oil on hydrogen peroxide treated rats. Int. J. Chem. Tech Res. 5, 1477-1485.

Alam Khan K. and Abrahem M. 2010. Effect of irradiation on quality of spices. International Food Research J. 17, 825-836.

Alshawi A.H. 2016. Study on the use of ionizing radiation for the preservation of spices. J. of environmental Sci., Toxicology and Food Technology. (10)9 Ver. III, 01-07.

Amariei S., Ciornei, S. and Sanduleac E. 2013. Antioxidant activity of some essential oils. Journal of Fac. of Food Engineering. Stefan Cel Mare Univ. of Suceava, Romania (XII) 2, 143147.

Amelia B., Saepudin E., Cahyana A.H., Rahayu D.U., Sulistyoningrum A.S. and Haib J. 2017. GC-MS analysis of clove (Syzygium aromaticum) bud essential oil from Java and Manado. Published in AIP Conference Proceeding 1862, American Institute of Physics.

AOAC 1996. Official Methods of Analysis of the Association of Official Analytical Chemists, $15^{\text {th }}$ Ed. Published by A.O.A.C., 2200 Wilson Boulevard Alington, Virginia 22201, U.S.A.
Atti-Santos A.C., Rossato M., Pauletti G.F., Rota L.D., Rech J.C., Pansera M.R., Agostini F., Atti-Serafini L. and Moyana P. 2005. Physicochemical evaluation of Rosmarinus officinalis $L$. essential oil. Brazilian Archives of Biology and Technology 48(6), 1035-1039.

Bakkali F., Averbeck S., Averbeck D. and Idaomar M. 2008. Biological effects of essential oils. A review. Food and Chemical Toxicology 46, 446-475.

Bensmira M., Jiang B., Nsabimana C. and Jian T. 2007. Effect of Lavender and Thyme incorporation in sunflower seed oil on its resistance to frying temperatures. Food Research International, 40, $341-346$.

Bobilev I., Novik V., Levi I., Shpilberg O., Levy J., Sharoni Y., Studzinski G.P. and Danilenko M. 2011. The Nrf2 transcription factor is a positive regulator of myeloid differentiation of acute myeloid leukemia cells. Cancer Biol. Therapy 11(3), 317-329.

Boisseau P. 1994. Irradiation and the food industry in France. Food Technology, 48, 138-140.

Bousbia N., Vian M.A., Ferhat M.A., Petitcolas E., Meklati B.Y. and Chemat F. 2009. Comparison of two isolation methods for essential oil from rosemary leaves: Hydro distillation and microwave hydro diffusion and gravity. Food Chemistry, 114, 355-362. 
Brand-William W., Cuvelier M.E. and Berset C. 1995. Use of a free radical method to evaluate antioxidant activity. Lebensm. Wiss. Technol., 28, 25-30.

British Pharmacopeia 2004. Incorporating the requirements of the $4^{\text {th }} \mathrm{Ed}$. of the European Pharmacopeia 2004 as amended by Supplements 4.1- 4.8. Vol. I. and IV. London, U.K.

Burdock A.G. 2010. Fenaroli's Handbook of Flavor Ingredients. 6th ed. CRC Press, Taylor \& Francis Group. New York, USA. 2162 p.

Clarke S. 2008. Essential Chemistry for Aromatherapy. $2^{\text {nd }}$ Ed. Churchill Livingstone Elsevier. $302 \mathrm{p}$.

Damjanovic B., Lepojevic Z., Zivkovic V. and Tolic A. 2005. Extraction of fennel (Foeniculum vulgare Mill.) seeds with supercritical CO2: Comparison with hydrodistillation. Food Chemistry, 92, 143-149.

Dimitrijević S.I., Mihajlovski K.R., Antonović D.G., Milanović-Stevanovic M.R. and Mijin D.Z. 2007. A study of the synergistic antilisterial effects of a sub-lethal dose of lactic acid and essential oils from Thymus vulgaris L., Rosmarinus officinalis L. and Origanum vulgare L. Food Chemistry, 104, 774-782.

Egyptian Standards 2007. Egyptian standard of cinnamon leaf oil. ES: 2377/2007. ISC: 71.100.60, Cairo, Egypt. Egyptian Organization for Standardization and Quality.

El-Baroty G.S.A.M. 1988. Biochemical Studies on some Naturally Occurring Substances and its Relation to Lipid Oxidation. Ph.D. Thesis, Fac. of Agric., Cairo Univ., Cairo, Egypt.

Elizalde J.J. and Espinoza M. 2014. Effect of ionizing irradiation on Origanum leaves (Origanum vulgare L.) essential oil composition. J. of Essential Oil Bearing Plants 14, 164-171.

European Pharmacopeia 2001. $4^{\text {th }}$ Ed., supplement 4.1, Published in accordance with the convention on the elaboration of a European Pharmacopeia 9European Treaty Series No. 50), Council of Europe, 67075 Strasbourg Cedex, France.

Farag R.S. and El-Khawas Kh.H. 1996. Influence of gamma irradiation and microwaves on the antioxidant property of some essential oils. International J. of Food Sci. and Nutrition 49(2), 109-115.

Farhoosh R. and Moosavi S.M.R. 2007. Rancimat test for the assessment of used frying oils quality. J. of Food Lipids 14, 263-271.

Fatemi F., Dini S., Rezaei M.B., Dadkhah A., Dabbagh R. and Naij S. 2014. The effect of $\gamma^{-}$ irradiation on the chemical composition and antioxidant activities of peppermint essential oil and extract. J. of Essential Oil Research 26, 97-104.

Giordani R., Regli P., Kaloustian J., Mikaïl C., Abou L. and Portuga H. 2004. Antifungal effect of various essential oils against Candida albicans. potentiation of antifungal action of amphotericin B by essential oil from Thymus vulgari. Phytotherapy Research, 18, 990- 995.

Guat W., Li S., Yan R., Tang S. and Quan C. 2007. Comparison of essential oils of clove buds extracted with supercritical carbon dioxide and other three traditional extraction methods. Food Chem. 101, 1558-1564.

Guenther E. 1961. The essential oils, Vol. I, II, IV, $4^{\text {th }}$ Ed. D. Van Nostr and Company, Inc. Princeton, New York, U.S.A.

Gulcin I., Elmastas M. and Aboul-Enein H.Y. 2012. Antioxidant activity of clove oil - A powerful antioxidant source. Arabian J. of Chemistry 5, 489-499.

Ibrahium M.I., Abd El-Ghany M.E. and Ammar M.S. 2013. Effect of clove essential oil as antioxidant and antimicrobial agent on cake shelf life. World J. of Dairy \& Food Sci. 8(2), 140146.

Khattak K.F. and Simpson Th.J. 2010. Effect of gamma irradiation on the antimicrobial and free radical scavenging activities of Glycyrrhiza glabra root. Radiation Physics and Chemistry, 79, 507-512.

Kim J.H., Shin M.H., Hwang Y.J., Srinivasan P., Kim J.K., Park H.J., Byun M.W. and Lee J.W. 2009. Role of gamma irradiation on the natural antioxidant in cumin seeds. Radiation Phys. and Chem. 78, 153-157.

Kirkin C., Mitrevski B., Gunes G. and Marriott P.J. 2014. Combined effects of gammairradiation and modified atmosphere packaging on quality of some species. Food Chemistry 154, 255-261.

Koleva I.I., Niederlander H.A.G. and Van Beek T.A. 2001. Application of ABTS radical cation for selective on-line detection of radical scavengers in HPLC elutes. Analytical Chemistry, 73, 3373-3381.

Lucchesi M.E., Chemat F. and Smadja J. 2004. An original solvent free microwave extraction of essential oils from spices. Flavour and Fragrance J., 19, 134 -138.

Machhour H., Hadrami I.E., Imziln B., Mouhib M. and Mahrouz M. 2011. Microbial decontamination by low dose gamma-irradiation and its im- 

from irradiated rosemary leaves and clove buds

pact on the physic-chemical quality of peppermint (Mentha piperita). Radiation Physics and Chemistry 80, 604-607.

Nurdjannah N. and Bermawie N. 2012. Handbook of Herbs and Spices Second Edition, edited by Peter, K.V. Wood head Publishing Series in "Food Sci., Technology and Nutrition", Cambridge pp. 197-215.

Politeo O., Jukie M. and Milos M. 2006. Chemical composition and antioxidant activity of essential oils of twelve spice plants. Croat. Chem. Acta, 79(4), 545-552.

Ranganna S. 1978. Manual of analysis of fruit and vegetable products. Tata. Mc - Graw -Hill Publishing Company Ltd., New Delhi, India.

Rojas-Cortes D.F., Fernands de Souza C.R. and Oliveira W.P. 2014. Clove (Syzygium aromaticum): a precious spice. Asian Pacific J. of Tropical Biomedicine 4(2), 90-96.

Rossel J.B. 1989. Measurement of rancidity. In Rancidity in Foods (Allen J.C. and Hamilton R.J., eds.) pp. 45-49, Elsevier Science Publishers Ltd., England.

Sadecka J. 2010. Influence of two sterilization ways, gamma-irradiation and heat treatment, on the volatiles of black pepper (Piper nigrum L.). Czech J. Food Sci. 28(1), 44-52.

Sadecka J. and Polovka M. 2008. Multiexperimental study of $\mathrm{y}$-radiation impact on oregano (origanum vulgare L.). J. of Food and Nutrition research 47, 85-91.

Sadecka J., Kolek E., Petka J. and Kovac M. 2005. Impact of gamma irradiation on microbial decontamination and organoleptic quality of oregano. In: proceedings of Euro Food Chem. XIII, Hamburg pp. 590-594.

Salum D.C., Araujo M.M., Fanaro G.B., Purgatto E. and Villavicencio A.L.C.H. 2009. Determination of volatiles produced during radiation processing in Laurus cinnamomum. Radiation Phys. and Chem. 78, 635-637.

Santoyo S., Cavero S., Jaime L., Ibanez E., Senorans F.J. and Reglero G. 2005. Chemical composition and antimicrobial activity of Rosmainus officinalis $L$. essential oil obtained via supercritical fluid extraction. J. Food Prot., 68(4), 790-795.

SAS 1996. SAS Procedure Guide. "Version 6.12 Ed.". SAS Institute Inc., Cary, NC, USA.

Silva T.M., Miranda R.R.S., Ferraz V.P., Pereira, M.T., Siquerira E.P. and Alcantara A.F.C. 2013. Changes in the essential oil composition of leaves of Echinodorus macrophyllus exposed to $\mathrm{y}$-radiation. Brazilian J. of Pharmacognosy 23, 600-607.

Statti G.A., Tundis R., Sacchetti G., Muzzoli M., Bianchi A. and Menichini F. 2004. Variability in the content of active constituents and biological activity of Glycyrrhiza glabra. Fitoterapia 75, 371-374.

Suhaj M. and Horvathova J. 2007. Changes in antioxidant activity induced by irradiation of clove (Syzygium aromaticum) and ginger (Zingiber officinale). J. of Food and Nutrition Research 46(3), 112-122.

Suhaj M., Racova J., Polovka M. and Brezova V. 2006. Effect of $Y$-irradiation on antioxidant activity of black pepper (Piper nigrum L.). Food Chemistry 97, 696-704.

Tsai P.J., Tsai T.H., Yu C.H. and Ho S.C. 2007. Evaluation of NO-suppressing activity of several Mediterranean culinary spices. Food Chem. Toxicol. 45(3), 440-447

Tucker A.O. and Maciarello M.J. 1986. The essential oils of rosemary cultivars. Flav. and Frag. J., 1, 137-142.

Urbain W.M. 1986. Food Irradiation. Academic Press, Inc., London, UK, 351 p.

Variyar P.S., Bandyopadhyay C. and Thomas P. 1998. Effect of gamma irradiation on the volatile oil constituents of some Indian spices. Food Research International, 31(2), 105-109.

Variyere P.S., Gholap A.S. and Thomas P. 1997. Effect of gamma-irradiation on the volatile oil constituents of fresh ginger (Zingiber officinale) rhizome. Food Research International 30(I), 41-43.

Wang W., Wu N.Y., Zu G. and Fu Y.J. 2008. Antioxidative activity of Rosmarinus officinalis L. essential oil compared to its main components. Food Chemistry, 108, 1019 -1022.

Wilkinson V.M. and Gould G.W. 1998. Food Irradiation. A reference guide. Wood head Publishing Ltd., Cambridge.

Yanishlieva N.V. and Marinova E.M. 1998. Activity and mechanism of action of natural antioxidants in lipids. Recent Research and Development in Oil Chemistry 2, 1-14.

Yen G.C. and Duh P.D. 1994. Scavenging effect of methanolic extracts of peanut hulls on freeradical and active-oxygen species. J. Agric. Food Chem., 42, 629-632.

Yesilbag D., Eren M., Agel H., Kovanlikaya A. and Balci F. 2011. Effects of dietary rosemary, rosemary volatile oil and vitamin $E$ on broiler performance, meat quality and serum SOD activity. Br Poult. Sci. 52(4), 472-482. 
Yosr Z., Hnia C., Rim T. and Mohamed B. 2013. Changes in essential oil composition and phenolic fraction in Rosmarinus officinalis L.var. typicus Batt. organs during growth and incidence on the antioxidant activity. Industrial Crops and Products, 43, 412 - 419.
Zegura B., Dobnik D., Niderl M.H. and Filipic M. 2011. Antioxidant and antigenotoxic effects of rosemary (Rosmarinus officinalis $L$.) extracts in Salmonella typhimurium TA98 and HepG2 cells. Environ Toxicol. Pharmacol. 32(2), 296-305. 
مجلة اتحاد الجامعات العربية للعلوم الزراعية ، جامعة عين شمس ، القاهرة ، مصر

مجلد(27)، عدد(2)، 1473-1459، 2019

Website: http://ajs.journals.ekb.eg

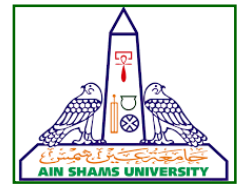

1473

الخصائص الفيزيوكيميائية والنشاط المضاد للاكسدة للزيوت العطرية المستخلصة من أولق الروز ماري ويراعم القرنفل المشعين

[120]

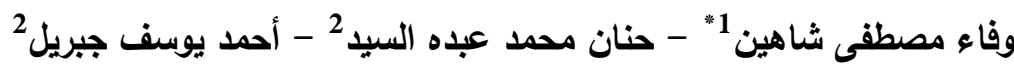

1- قسم الوقاية والدفاع الدنى - مركز البحوث النووية - هيئة الطاقة النرية المصرية - ص.ب.

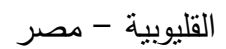

$$
\begin{aligned}
& \text { 2- قسم علوم الأغذية- كلية الزراعة- جامعة عين شمس - ص.ب 68- حائق شبرا } 11241 \text { - القاهرة - مصر }
\end{aligned}
$$

*Corresponding author: fefe2002@yahoo.com

Received 30 March, 2019 Accepted 23 April, 2019

المئوية لمكونات الزيوت العطرية. زاد النشاط المضاد

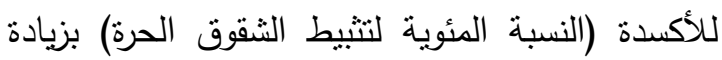

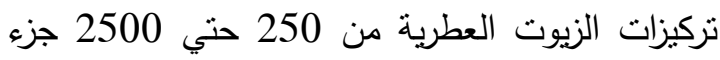
في المليون، علاوة علي ذللك، أمكن ملاحظة تأثنات التير

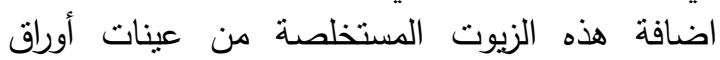

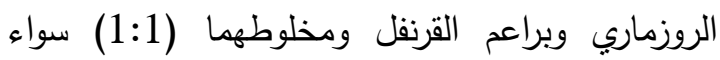

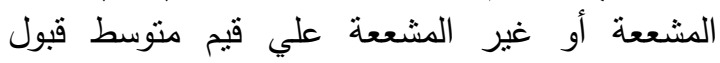
الرائحة. وضح اختبار الرانسمات الثبات الاكسيدي عئي

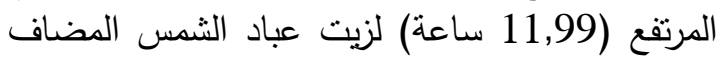
اليه 0,3 \% زيت قرنفل مستخلص من العينة المشععة الئة بجرعة 15 كيلوجراي بثنات نسبي قدره

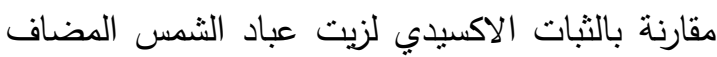

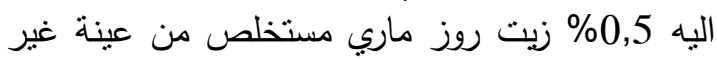

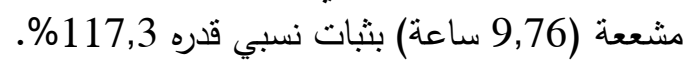

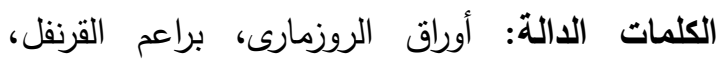
التشعيع، الزيت العطرى، GC/MS، النشاط الرضاد، الراع

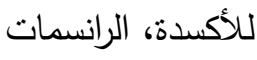

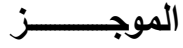

تم معالجة كل من الروز ماري (اكليل الجبل)

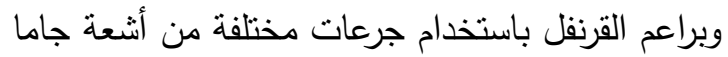
من (0 الي 30 كيلوجراي) وخزنت لمدة 12 شهر علي التئي

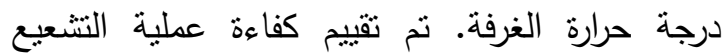
بالتحليلات الكيميائية وقياس النشاط المضادة المضاد للأكسدة

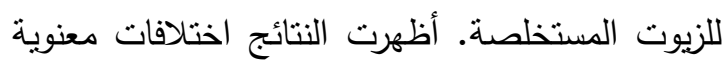

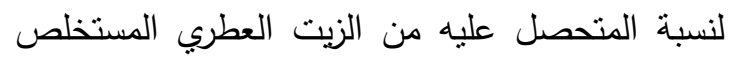

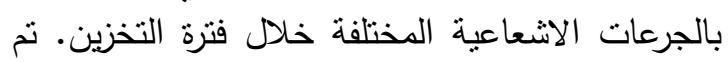

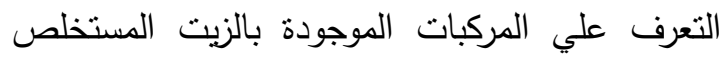
من العينات غير المشععة والمشععة لكل من أوراق المات المبات

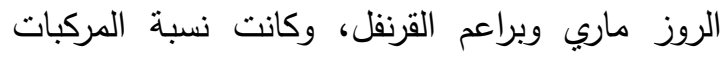

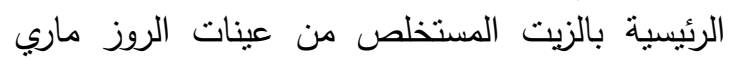
المشععة وغير المشععة 1,8 سينيول، كامفور وجاما لرنا

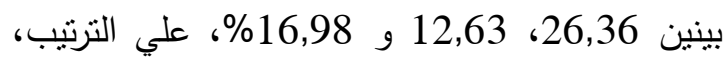

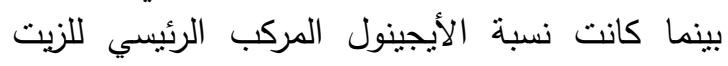

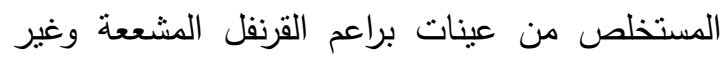
المشععة 81,69\%. لم يلاحظ اختلافات في النسبة 